\title{
Is consciousness a product of the brain or/and a divine act of God? Concise insights from neuroscience and Christian theology
}

\begin{tabular}{|c|c|}
\hline \multicolumn{2}{|c|}{$\begin{array}{l}\text { Author: } \\
\text { Mark Pretorius }^{1}\end{array}$} \\
\hline \multicolumn{2}{|c|}{$\begin{array}{l}\text { Affiliation: } \\
{ }^{1} \text { Department of Dogmatics } \\
\text { and Christian Ethics, Faculty } \\
\text { of Theology, University of } \\
\text { Pretoria, South Africa }\end{array}$} \\
\hline \multicolumn{2}{|c|}{$\begin{array}{l}\text { Project leader: J. Buitendag } \\
\text { Project number: } 02402343\end{array}$} \\
\hline \multicolumn{2}{|c|}{$\begin{array}{l}\text { Description: } \\
\text { Mark Pretorius is part of the } \\
\text { research project, 'Theology } \\
\text { of Nature', directed by Prof. } \\
\text { Dr Johan Buitendag } \\
\text { (Dean, Faculty of Theology), } \\
\text { Department Dogmatics and } \\
\text { Christian Ethics, Faculty of } \\
\text { Theology, University of } \\
\text { Pretoria, South Africa }\end{array}$} \\
\hline \multicolumn{2}{|c|}{$\begin{array}{l}\text { Corresponding auth } \\
\text { Mark Pretorius, } \\
\text { mark@sats.edu.za }\end{array}$} \\
\hline \multicolumn{2}{|c|}{$\begin{array}{l}\text { Received: } 09 \text { May } 2016 \\
\text { Accepted: } 09 \text { Aug. } 2016 \\
\text { Published: } 11 \text { Nov. } 2016\end{array}$} \\
\hline \multicolumn{2}{|c|}{$\begin{array}{l}\text { How to cite this article: } \\
\text { Pretorius, M., 2016, 'Is } \\
\text { consciousness a product of } \\
\text { the brain or/and a divine act } \\
\text { of God? Concise insights from } \\
\text { neuroscience and Christian } \\
\text { theology', HTS Teologiese } \\
\text { Studies/Theological Studies } \\
72(4), \text { a3472. http://dx.doi. } \\
\text { org/10.4102/hts.v72i4.3472 }\end{array}$} \\
\hline \multicolumn{2}{|c|}{$\begin{array}{l}\text { Copyright: } \\
\text { (C) 2016. The Authors } \\
\text { Licensee: AOSIS. This } \\
\text { is licensed under the } \\
\text { Creative Commons } \\
\text { Attribution License. }\end{array}$} \\
\hline \multicolumn{2}{|l|}{ Read online: } \\
\hline ariplas: & $\begin{array}{l}\text { Scan this QR } \\
\text { code with your } \\
\text { smart phone or } \\
\text { mobile device } \\
\text { to read online. }\end{array}$ \\
\hline
\end{tabular}

Over several years now, notable research has been undertaken on consciousness from various disciplines in the natural sciences, especially in neuroscience and Christian theology. This paper will therefore attempt to add to the current literature in these areas by addressing briefly the following three main aspects, namely, (1) Presenting a succinct explanation of the various views of consciousness by select scholars. (2) Exploring briefly the question, 'Is the emergence of consciousness a product of an evolved brain?' (3) Concisely examining the question, 'Is consciousness of God and spiritual experiences a divine act and/or a process of an evolved brain?'

\section{Introduction}

The purpose of this article is to briefly explore and appreciate the symbiotic nature of the brain and mind and its evolutionary pathway in generating consciousness, especially spiritual consciousness, leading to spiritual experiences. ${ }^{1}$ The projected model is to do a succinct narrative review of the various views of consciousness by select scholars over the past years, to illustrate that generally it is difficult to apply a proper working definition to consciousness. A concise discussion will also be undertaken to explore how consciousness could have emerged, and the importance of specific brain areas in the function of qualia consciousness and spiritual experiences. The current philosophy of animal consciousness will also be examined, and a brief analysis on whether consciousness is by divine act or/and by an evolutionary process will be considered.

\section{Consciousness cannot be defined}

Few would argue that over recent decades the relationship between the brain and the mind in producing consciousness has garnered substantial attention. This is especially so within the academic community of psychology, neuroscience and, recently, in Christian theology. Here, there is a common benefit in understanding how they link to further appreciate the relationship between God and human beings from a cognitive perspective, and how, to a certain extent, the mind and brain may generate spiritual experiences. Unfortunately, such a study does come with its own challenges, especially since the term consciousness is vague, and seemingly lacks a proper working definition. Here, the author would like to begin by quoting a few statements of how, over the past several years, some scholars have viewed consciousness and the challenge of defining it. To begin, the renowned cognitive scientist and philosopher David Chalmers presented and published a paper in 1995 entitled 'Facing up to the Problem of Consciousness'. In it, he pronounced 'There is nothing that we know more intimately than conscious experience, but there is nothing that is harder to explain' (1995:200-219). He is further noted for devising the term 'The Hard Problem of Consciousness', meaning it is difficult to define conscious experience.

William Struthers from Wheaton College in a paper written in 2001 said: 'Many experimental psychologists (as well as philosophers and theologians) have had difficulty providing a clear, complete and exhaustive operational definition for consciousness. Consciousness is a slippery term and many have attempted to frame a coherent description of what this term represents'. He further states '... the great American psychologist, William James, avoided explicitly defining consciousness'.

1.Please note that the author is aware and sensitive to the reality that spiritual experiences do happen within a broad range of religions. However, this study specifically concerns itself with interpreting and sketching out spiritual experiences within a biblical and Christian framework.

Note: Original Research: Volume 17 in the South African Science and Religion Forum Series, edited by Prof. Dr Cornel du Toit (UNISA) and Prof. Dr Danie Veldsman, entitled 'Creation, Consciousness and Christology: Evolutionary Perspectives', Proceedings of the 20th conference of the South African Science and Religion Forum (SASRF) of the Research Institute for Theology and Religion held at the University of South Africa, Pretoria, 16-18 September 2015. 
Anthony Freeman (2001:57) argued that since consciousness is not public (since it arises from an act of attention), it cannot be defined - one can only describe the event.

Cedric Evans maintains that 'Sometimes one will encounter a phenomenon which words cannot describe or define, therefore the person has to (consciously) experience it for themselves'. In that situation, he proposes 'We may feel inclined to say that the phenomenon cannot be defined cannot be given a defining description'. He further declares 'I conclude that the idea of giving a "real" definition of consciousness is absurd' (2004:46-47).

On this, Peter Russell makes a bold statement by offering 'There is nothing in physics, chemistry, biology or any other science that can account for our having an interior world [consciousness]. In a strange way, scientists would be much happier if there were no such thing as consciousness' (Russell 2005:17). He further suggests 'The word [consciousness] is not easy to define, partly because we use it to cover a variety of meanings' (Russell 2005:31).

Malcom Jeeves and Warren Brown in their book Neuroscience, Psychology and Religion determine that 'No one really knows for sure what creates the specific content of our consciousness, although most would agree that it is a product of the functioning of the cerebral cortex' (2009:50).

Andrew Newberg in his 2010 book Principles of Neurotheology submits that:

Consciousness is almost as difficult to grasp and consider as the relationship between mind and brain. In fact, in many ways, consciousness has been a greater problem for scholars because it has no tangible basis ... (Newberg 2010:26)

Peter Clarke in his recently released 2015 book All in the Mind writes 'How is it that a physical object such as the brain could ever give rise to consciousness ... this is the greatest mystery of all' (Clarke 2015:43).

\section{Describing consciousness}

Although the term consciousness is seemingly vague and perhaps lacks a proper working definition as presented by these scholars, one can certainly illuminate consciousness including which parts of the brain are activated during conscious and unconscious experiences. On this, there is much empirical data available. Precise locations of brain activity during these various conscious and unconscious experiences are now accessible through different means, especially by using functional MRIs and PET scans (cf. Giovannoli 2001; Newberg 2010:168-169; Newberg \& Waldman 2010:69-76; Verghese 2008:233-237). Here, neuroscientists can see in real-time, which parts of the brain are active when performing certain tasks. From this, they can extrapolate information and inform on the various levels, states and structures of consciousness (see Combs 2009:49-76), such as when one unconsciously experiences something during sleep, while under general anaesthetic, comatosed or in a vegetative state, ${ }^{2}$ including during subjective experiences, like when one meditates or prays.

Further, science is fairly confident that consciousness and its derivatives is a reciprocal product of brain activity and thought process, as proposed, for example, by Vanchevsky (2006:23). Therefore, while describing consciousness, one can say that in humans it suggests self-awareness and the capacity for introspection (see Thibault 2014:178-179). It would include the capacity to identify oneself as separate from the environment and other individuals. It is the desire and the ability to be able to seek a sense of understanding of oneself, in relation to the world, which distinguishes humans from the lower primates. This is explored further on.

\section{Qualia consciousness}

One can also refer to what is termed qualia consciousness or subjective conscious experiences. Although there are arguments for and against qualia experiences, the idea is that one has the subjective ability to appreciate beauty in sunsets, paintings and music, yet oppositely to also experience pain, distress and sadness, and to give thought to it. Interestingly, Kim Jaegwon in Murphy and Brown (2007:234) argues that unlike mental properties, which are reducible to physical properties, qualia are epiphenomenal. So although we may be aware of the same things, and perhaps looking at the same things, we have varied subjective experiences of those things. Ramachandran and Hirstein (1997:43) propose that 'Qualia give human conscious experience the particular character that it has'. Few would argue that qualia experiences are a wonderful part of our uniqueness as humans, which distinguishes our conscious experiences from that experienced by lower primates.

So although we have varied experiences of the same thing, what science cannot explain is the conscious (epiphenomenal) nature of these experiences, or, for that matter, what separates conscious thought from subconscious thought. To again quote William Struthers, 'consciousness is a slippery term'. It is precisely because of this that consciousness is difficult to define, although neuroscience has some idea of its origin from an evolutionary perspective and location in the brain. Here, a briefly sketched outline of the evolution of consciousness is presented. ${ }^{3}$

\section{The evolution of consciousness}

\section{Sponges}

The famed palaeontologist Simon Morris Conway (2013:155) proposes that complex structures that carried the biological components for consciousness date back roughly two billion years with the early emergence of complex cells called eukaryotes. According to him, '... important components of the nervous system are inherent in the eukaryotes' (2013:160). He further offers that even sponges, ${ }^{4}$ the most primitive of

2.Ground-breaking research conducted by Dr. Owen et al. (2006:1402), detected awareness in vegetative patients (see also Cruse \& Chennu 2012).

3.This is owing to space limitations and the author's restricted knowledge of evolutionary biology.

4.These and other complex multi-cellular life appeared during the Avalon explosion approximately 575 million years ago which brought about Ediacara life-forms, which included a variety of sponges and jelly fish (see Ross 2009:162; Shen et al. 2008:81-84). 
animals, contain eukaryotes and although sponges do not possess any kind of nervous system, sponge larvae do possess proteins associated with flask cells which are involved with post-synaptic activities. According to Sakarya et al. (2007:1-7), these flask cells seemingly help the larvae to sense their environment and could well have been a starting point for neurons to evolve. This, according to Morris (2013:159), has led to the interesting speculation that flask cells may in some way be the precursor to the nervous system, which is so very important for conscious experience. ${ }^{5}$

\section{Reticular activating system}

Further to this, Mark Solms (2014:181) upholds that simple forms of consciousness appear to have evolved at least 525 million years ago with the first emerging vertebrates during the explosive Cambrian period (see also Ross 2009:162; Shu et al. 1999:42-46). Here, Feinberg and Mallatt (2013) make an important observation and rightly declare '... it is undetermined when or how consciousness arose in the history of the vertebrate brain'. But interestingly, as the brain and nervous system evolved through fossil succession from these early life forms to the more complicated, so too emerged what is known as the reticular activating system (cf. Manger 2009:1413-1416).

To be conscious requires one to possess a functioning reticular activating system or RAS as some like to abbreviate it (see Mahadevan \& Garmel 2012:185). According to Mashour and Alkire (2013:10357-10364), neuroscience has shown that the RAS, located in the upper brainstem, is composed of several neuronal circuits connecting the brainstem to the cortex, meaning it is primarily responsible for many cognitive functions related to awareness. Therefore, it plays a major role, if not the most important role, in conscious experience. ${ }^{6}$ On this, Solms and Panksepp (2012:102-106) suggest that not only is the RAS responsible for many cognitive functions related to awareness but it also networks with what is called the periaqueductal grey, located in the midbrain.

\section{Periaqueductal grey}

Among its many functions, such as pain modulation and reproductive behaviour, the periaqueductal grey is also responsible for consciousness, as presented by Panksepp (1998) and Damasio (1999). One reason this is assumed is that although it is about the size of a jelly bean according to Solms, if damaged consciousness is lost. Further, the periaqueductal grey not only connects to consciousness but also to conscious experience. If, for example, one stimulates the dorsal columns, the back part of the periaqueductal grey, it generates quite unpleasant conscious feelings, such as pain and distress.

5. In this section, the author is not referring to the process of abiogenesis, meaning life emerged spontaneously from non-life, since he is fully convinced that this complex cell from where life emerged was initially created by God. Here, the author is referring to the most basic cell, the prokaryote (see Pretorius 2013).

6.The term reticular formation (reticular activating system) is used to encompass a large expanse of neurons scattered throughout the central nervous system, from the spinal cord to the forebrain. This distribution makes the definition and delineation of this neural system a difficult task to determine (see Mange 2009:1413-1416).
Conversely, if one stimulates the front part of the periaqueductal grey, the ventral columns, it generates pleasant sensations of consciousness (see Purves, Augustine \& Fitzpatrick 2001). Causing such reactions according to Solms and Panksepp (2012:147-175) is thought to be the biological 'purpose' of consciousness. Nonetheless, there are alternative views to emerging consciousness such as Panpsychism, considered one of the more exotic metaphysical ideas on consciousness. It is a view, according to Seager and AllenHermanson (2015), which has a fairly rich history, and is found in the philosophies of Vedanta and Mahayana Buddhism, including, for example, in the philosophical writings of Greek scholars, such as Thales, Plato and Aristotle.

\section{Panpsychism and consciousness}

In contrast to the standard evolutionary ideas on emerging consciousness, Peter Russell, for instance, argues for the ideas of Panpsychism, ${ }^{7}$ meaning that consciousness is a fundamental quality of nature. For him, consciousness is universal and not something that emerged, or in his words 'at any particular stage of biological evolution' (2005:36). Rather, he says, 'What emerged over the course of evolution was not the faculty of consciousness but the various qualities and dimensions of conscious experience-the forms of consciousness' (Russel 2005:37). The problem with Panpsychism is that although it has a rich history, it is subject to various interpretations. One may or may not agree with him, but what has emerged is that Panpsychism is making a fairly strong return, especially in philosophy. A further question to deal with regarding emerging consciousness is animal consciousness and how does it differ from human consciousness - if at all. This is especially important, since generally it is agreed that the biological components for consciousness began in sponges - the most primitive of animals, as proposed by Conway (2013:155). In his Harvard thesis, Joseph Vitti (2012), in dealing with evolving consciousness, states '... some nervous systems [in primitive animals] became so complex that they enabled their possessors not merely to process and respond to the environment, but to consciously experience it' (2010:13). Thus, it is an important topic in appreciating emerging consciousness and the continuous challenges it presents.

\section{Animals and consciousness}

The idea of animal consciousness was granted international attention on 07 July 2012, when a prominent group of international neuroscientists in most fields convening at Cambridge University signed a document called The Cambridge Declaration on Consciousness, ${ }^{8}$ which officially declared that 'non-human animals, including all mammals, birds and octopuses, are conscious'. The renowned neuroscientist Stanislas Dehaene (2014:242) strengthens their argument by saying that contributing consciousness to animals should not be based solely on their anatomy as

7.The doctrine or belief that everything material, however small, has an element of individual consciousness.

8.See http://fcmconference.org/img/CambridgeDeclarationOnConsciousness.pdf Edited by Low (2012). 
expressed by some scientists who argue that only vertebrates can experience consciousness since they possess an RAS. Rather, one should acknowledge that the topic of animal consciousness comes with its own set of difficulties. Nevertheless, the document further states that 'Evidence of near humanlike levels of consciousness has been most dramatically observed in African grey parrots'. ${ }^{9}$ They also profess that 'Certain animals exhibit REM sleep ... and Magpies in particular have been shown to exhibit striking similarities to humans, great apes, dolphins and elephants in studies of mirror self-recognition'. Hence, one can assume that the consciousness of certain species of animals seems advanced. At the end of the Cambridge document, these scholars declare:

We declare the following: 'The absence of a neocortex does not appear to preclude an organism from experiencing affective states. Convergent evidence indicates that non-human animals have theneuroanatomical,neurochemical, and neurophysiological substrates of conscious states along with the capacity to exhibit intentional behaviours. Consequently, the weight of evidence indicates that humans are not unique in possessing the neurological substrates that generate consciousness ... .' (2012)

Although a compelling statement, one should characterise what type of consciousness they are referring to. Humans, unlike animals, are more than just conscious, meaning, we not only have qualia consciousness but we are also self-aware, that is, we internalise things. Although science in general disagrees on the difference between consciousness and self-awareness, there is a fairly universal explanation. Consciousness, for example, is awareness of one's body and one's environment animals possess this. However, self-awareness from a human perspective is recognition of that consciousness. Newberg and Waldman (2010:172) refer to it as being aware of one's body in relation to the world. So it is not only the understanding that one exists but further understanding that one is aware of one's existence in this world. In other words, humans have the ability to be able to seek a sense of understanding of themselves, and their external world. One may assume that future studies would either confirm or deny that all animals have this type of consciousness. Here, Dehaene (2014:244) makes a sober proposal. He suggests that although animals cannot describe their conscious thoughts, it does not mean that they do not have any.

Further, Dehaene (2014:250) suggests that although some animals, such as monkeys, for example, possess a conscious neuronal workspace and may use it to ponder themselves and the external world, humans undoubtedly display superior introspection. On this, he tentatively proposes that although we share most if not all of our core brain systems with other animal species, the human brain may be unique in its ability to combine them using a sophisticated, as he puts it, 'language of thought' (2014:250). What he means by this is, and here he acknowledges the thoughts of René Descartes, that humans have the capacity to compose their thoughts into words and declare them to others. He approximates that this capacity to compose thoughts may be the critical ingredient that boosts a person's inner thoughts. In this way, humans have the unique ability to think and propose new ideas along with the ability to share these ideas with others using language, or even by stringing symbols together that convey a message. In addition, Dehaene (2014:251) speculates that this compositional language of thought underlies many uniquely human abilities from the design of complex tools, to creating higher mathematics. Moving to the issue of evolution and spiritual consciousness, the following should be noted.

\section{Evolution and spiritual consciousness}

There is a recognised distinction between ordinary consciousness and awareness as revealed by evolutionary science and spiritual consciousness. The first deals with naturally occurring consciousness as was shown, while spiritual consciousness is metaphysical in its understanding. It transcends the ordinary. Ordinary awareness is governed, to a certain extent, by one's senses. Conversely, spiritual awareness - in the Christian sense - transcends the ordinary. It is a supernatural yet conscious awareness of the divine. As offered by Newberg and Waldman (2010:67), 'God is much more than an idea. God is a deeply valued experience that goes far beyond any theological definition ...'. Here, some may be offended by the idea that God is referred to as an experience, but one should consider that God (in the Christian sense) has no tangible existence. In John 1:1 and 4:2, God is referred to as the Spirit Pnema ho Theos. God as the Spirit has no tangible existence, so Christians experience God in the form of his power (his Spirit) to work in them to bring enlightenment of his presence. In some denominations, it is referred to as a spiritual awakening - a supernatural work imparted to people by God's Spirit. In traditionally Charismatic and Pentecostal theology, for example, it implies that one's spirit is renewed and one is born-again (enlightened to God) as mentioned in John 3:3; 5-7 and 2 Corinthians 5:17. A spiritual awakening is therefore not a direct product of evolution but a consequence of the evolution of the brain and consciousness. Thus, God works in people by using the faculties of an evolved brain to bring about supernatural spiritual experiences. But this does not answer the question posed. Is the evolution of consciousness, the brain and spiritual experiences all a product of God's divine intervention?

\section{God and spiritual experiences}

Although it was briefly shown that consciousness is seemingly a slippery term, its short meaning is the 'ability to be consciously aware', and here, most would agree. So when one is aware of something, like a spiritual awakening, it means that they are aware of a higher power or a divine being. As stated, in Christianity, it would be an awareness of God. Here, the idea of qualia consciousness, if one expands it, is significant since we often experience God differently, especially at a cognitive level. On this, Deepak Chopra (2014) upholds that although qualia at its most basic level is the Latin word for quality, meaning the sight, sound, touch and 
taste of things, it also applies to the mental level. In this case, mentally God becomes unique to me and my situation. How he guides and reveals himself to me is different from how he would deal and reveal himself to others. One could expectantly say that everyone has a unique conscious spiritual experience with God, since this is how optimistically we could see qualia consciousness working from a spiritual perspective. David Chalmers (1996) refers to this as the riddle of first-person subjectivity. Chopra and Kafatos (2014:287-301) reason that '.. because qualia are subjective, they sharply challenge the dominant world view of modern science, which is reductionist, objective, and mathematical'. Here, what can be proposed is the question why it is difficult to find a common working definition for consciousness.

So, in general terms, we can say that a spiritual awakening is an altered state of perception. It is a knowing beyond knowledge. It is supernatural. As a Christian, the author is convinced that God is the one who causes a conscious spiritual awakening and personally reveals himself to individuals in their own unique way. Expressly, they become conscious of God. But the question is how? Edward Newberg (2010:54-56) proposes that people become aware of God through an activation of their thalamus, which he refers to as the Grand Central Station of sensory processing. The thalamus also connects with the reticular activating system, which as briefly explained, occupies a key role in awareness and conscious experience.

\section{God and the brain}

But in saying this, experimental research by neuroscience has shown that there is no specific God-spot, but rather that numerous areas of the brain are activated when, for instance, one prays and meditates. Here, there have been several good empirical studies undertaken to establish this, like those, for example, of Newberg and Waldman (2010:69-76), Verghese (2008:233-237), Giovannoli (2001) and D'Aquili and Newberg (1999). However, Jeeves and Brown (2009:99) do advocate caution on going down this road too simplistically. They argue that one cannot, and should not, reduce religion to a primary form of cognitive activity. Other factors, one can rightly assume, must be considered, such as upbringing (family environment), social interaction - especially with peers, education and of course the awareness that God can and does supernaturally intervene to bring about spiritual experiences as recorded in Scripture. For example, each time a believer was supernaturally filled with the Spirit of God, the immediate result was an infusion of God's power for ministry. As a result, the Christians prayed, sang, prophesied (Lk. 1:4-6), spoke in tongues (Ac. 2:4; 14), preached the gospel (Acts 4:8-12) and rebuked those empowered by demons (Ac. 13:9-11) (cf. Pretorius \& Lioy 2012:60-62, 81). However, the author would like to further consider the concerns expressed by Jeeves and Brown by asking two questions.

Firstly, is religion or an awareness of God, a product of brain evolution like consciousness? There are various ideas that have been put forward on this, such as HADD (hyperactive agency detection device) and of course John Calvin's sensus divinitatis [sense of divinity]. In an indirect way, both these views maintain that a belief in God is generated naturally and directly by a God-implanted cognitive faculty that needs no reasoning, meaning it is a natural and direct product of theevolution of the brain ${ }^{10}$ (seeClarkand Barrett2010:174-189). This is further maintained by Kurt and Wegner (2010:9-10) who propose that HADD is likely to be a 'foundation for human belief in God'. This, in a sense, according to Clarke (2015:215), would confirm the claim made by Christians that we are made for God, to know him and to love him.

Although there are arguments for and against HADD, those in the disciplines of biology and psychology tend to argue that it is probably the most widely accepted explanation for religious belief (see Antes, Geertz \& Warne 2004:406-410; Van Slyke 2013:124-127). Here, the Christian philosopher Michael Murray (2008) refers to it as '... the most widely endorsed cognitive account of the origins of religious belief'. Although he is critical of it, he does state that 'Perhaps God set up our environment and the course of evolutionary history in such a way that we come to have cognitive tools that lead us to form beliefs in a supernatural reality' (2008:396). In the author's view, although the brain may have this built-in mechanism which is the result of an evolution of the brain, the author proposes that it is solely and directly activated by God during a spiritual experience, especially where one comes to realise that God is real. By this, it is meant that the person has had a dramatic experiential encounter with the God of the Bible.

Secondly, why should Christians concern themselves with the study of consciousness, especially conscious and spiritual experiences? Here, the author would like to present two reasons although there may be others, which seem to confirm the ideas of, especially that of HADD, and in fact, expand on them.

Firstly, appreciating the significance of consciousness is important since it is near the heart of Christian experience. As a Charismatic Christian, the author believes that understanding how the link between mind and brain can improve a Christian's conscious and spiritual experiences of God is important. Therefore, it is essential for Christian scholars and church leaders to involve themselves in the study of psychology and neuroscience to develop an awareness of the importance of the mind and brain in helping Christians to recognise and appreciate valid spiritual experiences. On this, Dick Cole (1998:210-219) reasons that 'The physical process of the mind/ brain is the vehicle for expression of Christian experiences'. Rob Moll (2014:17) contends that '... research is quickly accumulating (that) our bodies, down to our cells and DNA, are designed for spiritual experiences'. Hence, it is an important study and the reason why Andrew Newberg's book Principles of Neurotheology is an essential read. He wrestles fairly successfully with the subject, especially the ideas related to how the brain and mind generate spiritual experiences, and the importance of understanding how this happens. Others, 10.It is fairly well accepted that Stewart Guthrie was the first to develop an evolutionary explanation of religious belief in his 1993 book Faces in the Clouds: A New Theory of Religion. 
such as Cedric Evans (2004), Malcom Jeeves and Warren Brown (2009) and Peter Clarke (2015), have also shown through much of their empirical studies the importance of understanding that the mind and the brain coexist in a symbiotic relationship, meaning, that together they give rise to our thoughts and feelings, including natural and spiritual experiences. Although the Scripture, according to William Struthers (2001:102-106), may have little to say about the reciprocal link between the mind and the brain, or the nature of what our mental life is made of, it does highlight that our mental life (or conscious being) is an integral part of our relationship with Christ.

Secondly, the issue of free will and how it works is important, especially since it has to do with causality and the results of our conscious free choices. As given by Newberg (2010: 212), 'The notion of the will itself may be derived in large parts from the functioning of the prefrontal cortex which enables us to make decisions regarding actions and behaviours as well as helps us to control emotional responses'. This is a significant statement, since within some sects of the Charismatic, Pentecostal and especially Word of Faith churches, there tends to be an overemphasis of seeking supernatural experiences at the expense of emotional control (see Gl. 5:16-24) and being of sound mind as expressed by 2 Timothy 1:7. Many within these denominations give their free will over to some kind of manifested power that could perhaps be nothing but a neurobiological experience. Some of these experiences range from the more traditional, such as glossolalia, speaking and prophesying in tongues, seeing into the spiritual realm, falling under the power of the 'Holy Spirit', to the more exotic and mystical (see Newberg 2010:11). Reasonably, there are some spiritual experiences that are scriptural and do take place, but they must be correctly discerned and interpreted (see Pretorius \& Lioy 2012:145-162). But as Newberg (2010:147) rightly argues, both biology and phenomenological experiences are relevant. It is the biology that helps to interpret and make use of religious experiences, but it is the religious experience that might lead to a deeper understanding of the human person and his or her ability to make proper ethical decisions, meaning, what is right and wrong when confronted with a spiritual experience. The author is persuaded that God uses our biological make-up to bring about spiritual experiences which make him more real, but these experiences must be correctly understood and where necessary constrained, so that they do not lead to ungodly and unethical practices that bring reproach against the church. Every person has been given the gift of free will, and God expects us to righteously and ethically use it for good. As cautioned by Newberg (2010:237), the human brain is easily manipulated into doing bad things; therefore, understanding the nature of the ways it can be manipulated can help to prevent such corruption with the human person. As earlier advocated by Jeeves and Brown (2009:99), one must exercise caution on going down this road too simplistically, and not reduce religion (or religious experiences) to a primary form of cognitive activity. There must be balance between what is spiritually experienced, and what the Scripture has to say on the matter.
Emotional responses also seem to go back to the free will exercised by Adam and Eve in the classical story of the Garden of Eden and emerging universal sin. There was an emotional appeal, an appeal to the senses to please the flesh. But free will is more than that. It is also taking responsibility for the consequences of those choices. Here, we are dealing with the ethics of choices. Newberg (2010:213) proposes that emotions, which are related to brain function (we are emotional beings), is relevant to ethics. He goes on to say that:

Any ethical decision process necessarily requires an ability to place emotional value on various elements. The value placed on each element of an ethical decision process is ultimately determined by our emotional perspective. The emotional perspective, in turn, is determined by our basic brain function. Our past experiences, and our cultural, philosophical, and spiritual background. (Newberg 2010:213)

To conclude and answer the question whether the evolution of the brain, consciousness and spiritual experiences are a product of God, the following should be considered. In a sense, spiritual consciousness could not exist without the emergence of consciousness, the brain and the nervous system by evolution. It is thus not an either or, rather that, together they are a product of God. One by a process of guided evolution (brain and consciousness), and the other by a supernatural impartation by God through the faculties of emergent consciousness and the brain.

\section{Conclusion}

While the debate around the brain (mind), consciousness and spiritual experiences on cognitive processes remains challenging and difficult to define, there is enough available information to make sense of it, and come to a fairly reasonable working model on its evolutionary pathway, and the symbiotic nature of the brain and mind in producing consciousness and spiritual experiences. Further, the thoughts on animal consciousness were also briefly explored, and it was shown that much research is still required to expand on what current research has to say on animal consciousness and what they may experience. It was further submitted that God (as seen within a biblical and Christian framework) has structured human cognitive capacities in such a way that when functioning properly, they result in religious beliefs and spiritual experiences. Here, the works of Newberg and Waldman (2010:69-76), Verghese (2008:233-237) and Giovannoli (2001) were referred to as showing that there are parts of the brain that generate consciousness, and, as expressed by Clark and Barrett (2010:174-189), intuitively give one a sense of the divine, vis-à-vis HADD or Sensus Divinitatus. It was further proposed that although there is an evolutionary pathway to consciousness and eventual spiritual conscious experiences, they do not deflect from the first cause which is God. Our cognitive tools are, it turns out, configured in such a way that they are highly liable to trigger belief in and commitment to supernatural reality, especially within a Christian framework. 


\section{Acknowledgements Competing interests}

The authors declare that they have no financial or personal relationships which may have inappropriately influenced them in writing this article.

\section{References}

Antes, P., Geertz, A.W. \& Warne, R.R. (ed.), 2004, New approaches to the study of religion: Textual, comparative, sociological, and cognitive approaches, Walter de Gruyter Publishers, New York.

Chalmers, D., 1995, 'Facing up to the problem of consciousness', Journal of Consciousness Studies 2(3), 200-219.

Chalmers, D.J., 1996, The conscious mind: In search of a fundamental theory, Oxford University Press, Oxford.

Chopra, D., 2014, The future of God: A practical approach to Spirituality for our times, Random House, New York, NY

Chopra, D. \& Kafatos, M.C., 2014, 'From quanta to qualia: How a paradigm shift turns into science', Philosophy Study 4(4), 287-301.

Clarke, P., 2015, All in the mind: Does neuroscience challenge faith? Lion Books, Oxford.

Cole, D., 1998, 'Against the integration of psychology and Christianity: A bold proposal for an alternative paradigm', Journal of Psychology and Christianity 17(3), 210-219.

Combs, A., 2009, Consciousness explained better: Towards an integral understanding of the multifaceted nature of consciousness, Paragon House, Minnesota, MN.

Cruse, D. \& Chennu, S., 2012, 'Detecting awareness in the vegetative state: Electroencephalographic evidence for attempted movements to command', PLoS One 7, e49933. http://dx.doi.org/10.1371/journal.pone.0049933

Damasio, A.R., 1999, The feeling of what happens: Body and emotion in the making of consciousness, Harcourt Brace, New York.

D’Aquili, E. \& Newberg, A.B., 1999, The mystical mind: Probing the biology of religious experiences, Fortress Press, Minneapolis, MN.

Dehaene, S., 2014, Consciousness and the brain: Deciphering how the brain codes our thoughts, Penguin Books, New York.

Evans, C.O., 2004, The subject of consciousness, vol. 6, Routledge, London

Feinberg, T.E. \& Mallatt, J., 2013, 'The evolutionary and genetic origins of consciousness in the Cambrian Period over 500 million years ago', Frontiers in Psychology 4, 667. http://dx.doi.org/10.3389/fpsyg.2013.00667

Freeman, A., 2001, The emergence of consciousness, Imprint Academic, Exeter

Giovannoli, J., 2001, The biology of belief: How our biology biases our beliefs and perceptions, Rosetta Press, Brooklyn, NY.

Guthrie, S., 1993, Faces in the clouds: A new theory of religion, Oxford University Press, Oxford.

Jaegwon, K., 1984, 'Concepts of supervenience', Philosophy and Phenomenological Research, in Murphy, N. \& Brown, W.S., 2007, Did my neurons make me do it? Philosophical and neurobiological perspectives on moral responsibility and free will, Oxford University Press, Oxford. 153-176.

Jeeves, M. \& Brown, W.S., 2009, Neuroscience, psychology and religion: Illusions, delusions, and realities about human nature, Templeton Press, West delusions, and reat
Conshohocken, PA.

Kurt, G. \& Wegner, D., 2010, 'Blaming God for our pain: Human suffering and the divine mind', Personality and Social Psychology Review 14(1), 9-10.

Low, P., Hawking, S., Pepperberg, I., Reis, D., Pfaaf, D., Boyden, E., et al., 2012, (ed) Low, P., 'The Cambridge declaration on consciousness', in Publicly proclaimed at Churchill College in Cambridge, UK, at the Francis Crick Memorial Conference on Consciousness in Human and non-Human Animals, July 7, 2012.

Mahadevan, S.V. \& Garmel, G.M., 2012, An introduction to clinical emergency medicine, 2nd edn., Cambridge University Press, Cambridge.

Manger, P.R., 2009, 'Evolution of the reticular formation', in M.D. Binder, D. Hirokawa \& N. Windhorst (eds.), Encyclopedia of Neurosciences, pp. 1413-1416, SpringerVerlag, Berlin.
Mashour, G.A. \& Alkire, M.T., 2013, 'Evolution of consciousness: Phylogeny, ontogeny, and emergence from general anesthesia', Proceedings of the National Academy of Sciences of the United States of America 110(suppl. 2), 10357-10364. of Sciences of the United States of America
$\mathrm{http}: / / \mathrm{dx}$.doi.org/10.1073/pnas.1301188110

Moll, R., 2014, What your body knows about God: How we are designed to connect, serve and thrive, InterVarsity Press, Downers Grove, IL.

Morris Conway, S., 2013, 'Evolution and the inevitability of intelligent life', in P. Harrison (ed.), The Cambridge companion to science and religion, pp. 148-172, Cambridge University Press, Cambridge.

Murray, M., 2008, 'Four arguments that the cognitive psychology of religion undermines the justification of religious belief', in J. Bulbulia, R. Sosis, E. Harris, R. Genet, C. Genet \& K. Wyman (eds.), The evolution of religion: Studies, theories, \& critique, pp. 365-370, Collins Foundation Press, Santa Margarita, CA.

Newberg, A., 2010, Principles of neurotheology, Ashgate Publishing, Surrey.

Newberg, A. \& Waldman, M.R., 2010, How God changes your brain: Breakthrough findings from a leading neuroscientist, Ballantine Books, New York.

Owen, A.M., Coleman, M.R., Boly, M., Davis, M.H., Laureys, S. \& Pickard, J.D., 2006, 'Detecting awareness in the vegetative state', Science 313(5792), 1402. http://dx.doi.org/10.1126/science.1130197

Panksepp, J., 1998, Affective neuroscience: The foundations of human and anima emotions, Oxford University Press, New York.

Pepperberg, I.M., 2002, The Alex studies: Cognitive and communicative abilities of grey parrots, Harvard University Press, Cambridge, MA

Pretorius, M., 2013, 'The remarkable cell: Intelligently designed or by evolutionary process?', Verbum et Ecclesia 34(1), 1-8.

Pretorius, M. \& Lioy, D., 2012, The Holy Spirit: A systemised study of the spirit's person and work, South African Theological Seminary Press, Johannesburg.

Purves, D., Augustine, G.J. \& Fitzpatrick, D. (eds.), 2001, The internal anatomy of the spinal cord, in D. Purves, G.J. Augustine \& D. Fitzpatrick, Neuroscience, 2nd edn., Sinauer Associates, Sunderland, MA, viewed April 2015, from http://www.ncbi. nlm.nih.gov/books/NBK11008/

Ramachandran, V.S. \& Hirstein, W., 1997, 'Three laws of qualia: What neurology tells us about the biological functions of consciousness, qualia and the self', Journal of Consciousness Studies 4(5-6), 429-458.

Ross, H., 2009, More than a theory, Baker Books, Grand Rapids, MI.

Sakarya, O., Armstrong, K.A. \& Adamska, M., Adamski, M., Wang, I.F., Tidor, B. et al. 2007, 'A post-synaptic scaffold at the origin of the animal kingdom', in L. Vosshal (ed.), PLoS One. 2(6), e506. http://dx.doi.org/10.1371/journal.pone.0000506

Seager, W. \& Allen-Hermanson, S., 2015, 'Panpsychism', in E.N. Zalta (ed.), The Stanford Encyclopedia of Philosophy, Fall edn., viewed 8 September 2015, from http:// plato.stanford.edu/entries/panpsychism/\#2

Shen, B., Dong, L., Xiao, S. \& Kowalewski, M., 2008, 'The Avalon explosion: Evolution of Ediacara morphospace', Science 319(5859), 81-84. http://dx.doi.org/10.1126/ science.1150279

Shu, D.-G., Luo, H.-L., Conway Morris, S., Zhang, X.-L., Hu, S.-X., Chen, L. et al., 1999 'Lower Cambrian vertebrates from South China', Nature 402,(6757), 42-46. http://dx.doi.org/10.1038/46965

Solms, M., 2014, 'A neuropsychoanalytical approach to the hard problem of consciousness', Journal of Integrative Neuroscience 13(2), 173-185. http://dx.doi. org/10.1142/S0219635214400032

Solms, M. \& Panksepp, J., 2012, 'The "Id" knows more than the "ego" admits: Neuropsychoanalytic and primal consciousness perspectives on the interface between affective and cognitive neuroscience', Brain Sciences 2(2), 147-175. http://dx.doi.org/10.3390/brainsci2020147

Struthers, W., 2001, 'Defining consciousness: Christian and psychological perspectives', Perspectives on Science and Christian Faith 53, 102-106.

Thibault, P., 2014, Agency and consciousness in discourse: Self-other dynamics as complex system, Continuum International Publishing, New York.

Vanchevsky, M.A., 2006, Frontiers in cognitive psychology, Nova Science Publishers, New York.

Van Slyke, J.A., 2013, The cognitive science of religion, Ashgate Publishing, Surrey.

Verghese, A., 2008, 'Spirituality and mental health', Indian Journal of Psychiatry 50(4), 233-237. http://dx.doi.org/10.4103/0019-5545.44742

Vitti, J., 2012, 'The distribution and evolution of animal consciousness', Honours Thesis, Harvard University Press, Cambridge, MA. 